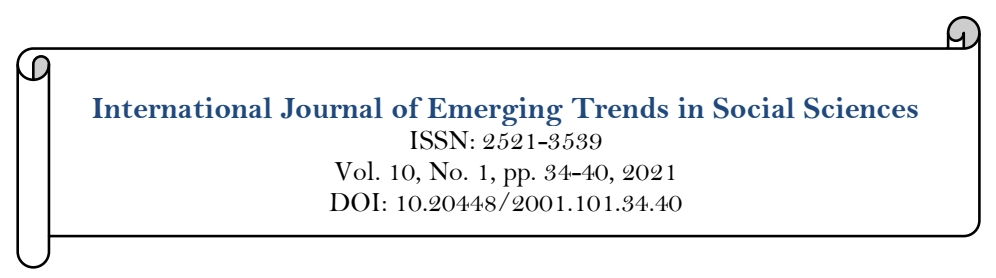

\title{
Application of Translation Workshop to College English Translation Teaching
}

\author{
Shan Ge \\ Beijing Institute of Petrochemical Technology, Beijing, China. \\ Email:geshan@bipt.edu.cn
}

\begin{tabular}{l|l}
\multicolumn{3}{|c}{ Abstract } & \\
Undergraduate education throughout the world has long been confronted & Keywords: \\
with the challenge of making students active learners who are responsible for & Student-centered \\
their own learning. It has been widely recognized that higher education & Translation workshop \\
needs to turn to student-centered perspective and model which emphasizes & Translation teaching \\
students' learning effect, or the outcomes of talent training. The traditional & \\
"teaching-centered" translation training mode adopted to teach non-English & Licensed: \\
majors in Chinese universities cannot effectively improve students' & This work is licensed under a \\
translation ability, though it may assist English language learning. The & Creative Commons Attribution 4.0 \\
teaching mode of "translation workshop", aiming at improving students' & License. \\
learning effect, emphasizes the learning process and enables students to learn & Publisher: \\
and improve translation skills through real translation project, which is & Scientific Publishing Institute \\
conducive to raising students' awareness of cross cultural communication & Received: 17 December 2020 \\
and cultivating their sense of responsibility as translators. The experiment & Revised: 12 January 2021 \\
done in the present study proves that applying "translation workshop" to & Accepted: 2 February 2021 \\
teaching Chinese non-English majors can effectively stimulate students' & Published: 15 February 2021 \\
interest in learning, increase their participation in learning, and thus & \\
improve the effect of translation learning. &
\end{tabular}

Funding: Student-centered Teaching Reform of College English Translation at Beijing Institute of Petrochemical Technology (Project No.: ZDFSGG20190901).

Competing Interests: The author declares that there are no conflicts of interests regarding the publication of this paper.

\section{Introduction}

To improve the quality of education and cultivate high-quality talents is the fundamental task of higher education. In the 1990s, Chinese universities began to introduce the American "student-centered" education concept, trying to reform the teaching methods and management of undergraduate education. The Declaration of Higher Education in the 21st Century: Vision and Action pointed out that higher education obviously needs "student-centered" perspective and model, predicting that the new concept of student-centered education will have a far-reaching influence on higher education in the 21 st century (Chen, $\mathrm{Li}, \& \mathrm{Hu}, 2012$ ). In the past 50 years, the practice of higher education reform in the United States and European countries shows that it is scientific, effective and feasible to implement in higher education the "student-centered" and "outcome-based" concepts and create a quality culture of continuous improvement. "Student centered education and teaching reform is the trend and requirement of the quality development of higher education, and it is also an important way for colleges and universities to cultivate high-quality talents" (Liu \& Zhao, 2018).

With the deepening of economic globalization, the social demand for translation talents is also increasing. To meet the demand, College English, a course aimed at non-English majors in Chinese universities, has been facing the responsibility of educating students to be professionals with bilingual translation ability. Translation ability is the comprehensive embodiment of college students' English ability. The selective course "College English Translation", as an integral part of College English teaching, has become an important course to cultivate non-English majors' cross cultural communication ability. At present, the translation teaching of non-English majors in China is still centered on "teaching", which focuses on "classroom, teachers 
and teaching materials". "Teaching-centered" mode attaches importance to teachers' imparting knowledge to students, and thus ignores allowing students to discover and construct knowledge by themselves, which leads to poor "learning effect". Students often find it hard to develop their translation ability and even harder to adapt to the needs of globalization. Therefore, under the guidance of "student-centered" education concept, the reform of College English translation teaching mode is of great practical significance to cultivate students' translation awareness and hone their translation skills.

\section{Development and Connotation of "Student-Centered" Education Concept}

In 1951, Carl Rogers, an American psychologist, first put forward the "student-centered" concept at an academic seminar held by Harvard School of Education, which advocated that students should set learning goals and evaluate their progress by themselves, so that students can become self-responsible learners (Chen, 2017). In the mid-20th century, American scholars put forward the concept of "student-centered" undergraduate education, which triggered a series of changes in the basic concept, teaching methods and teaching management of undergraduate education, and brought great influence to higher education (Liu, 2012). In 1995, Barr R. B. and Tagg J. published "From Teaching to Learning: a New Paradigm for Undergraduate Education" in Change, an American journal of university education, which termed the traditional controlled undergraduate teaching paradigm as "instruction paradigm" and pointed out that "learning paradigm", a new educational paradigm, is taking shape. They made a detailed comparison between instruction paradigm and learning paradigm in six aspects: task objectives, success criteria, teaching structure, learning theory, productivity \& funding, and role nature (Chen, 2017). In 1998, UNESCO put forward in the declaration of the 1st World Conference on Higher Education that higher education needs to turn to studentcentered perspective and model. It required international higher education policy makers to focus on students and their needs, and regard students as the main participants in education reform. It also predicted that student-centered concept will exert a profound impact on the 21 st century higher education in the whole world.

On July 14, 2012, at the International Academic Conference on Institutional Research: Student Centered Undergraduate Education Reform, jointly held by the academic research branch of China Association of Higher Education and Huazhong University of Science and Technology, professor William Barone of Duke University pointed out that the United States, the European Union and China have successively popularized higher education, and universities are no longer places for elite education. The whole world is confronted with the challenge of making students active learners who are responsible for their own learning (Liu, 2012). There is a general consensus in the field of education about the need for student-centered educational reform to improve the quality of talent training. How to systematically promote and effectively implement the studentcentered concept in all aspects of higher education is a common issue faced by institutions of higher education, and also is an inevitable requirement for the quality development of higher education (Liu \& Zhao, 2018).

"Student centered" educational concept, derived from constructivist learning theory, emphasizes students' active exploration, discovery and construction of knowledge. Being student-centered does not mean superiority of students over everyone else, but rather a change in teaching concepts, teaching methods and evaluation measures. The most fundamental of "student-centered" concept is to realize the transformation from "teaching centered" to "learning centered". Schools should divert attention to students' learning by changing from the three old centers of classroom, teachers, and teaching materials to the three new centers of students, learning, and learning process (Liu, 2012). The essence of "student-centered" concept is to promote students' autonomous learning and all-round development, which is featured by: 1) highlighting students' subject status and allowing students to have autonomy; 2) caring about students' development needs, reasonably formulating teaching objectives, elaborately designing teaching activities and creating situations and conditions for students' learning; 3) paying attention to students' learning process and effectively mobilizing students' enthusiasm 4) emphasizing students' learning effect, and bringing "learning" into the evaluation system (Liu \& Zhao, 2018). Based on these four features and striving to solve the problems in present College English translation teaching, the author takes her selective translation class of 2020 fall semester as the experimental class to explore the ways and effect of applying translation workshop to teaching non-English majors translation.

\section{Application of Translation Workshop to College English Translation Teaching}

Since 2013, the Ministry of Education of China has put forward the quality evaluation concept of "student-centered", "outcome-based" and "continuous improvement". Chen (2017) collected the evaluation records done by 309 experts about the classroom teaching in 51 universities in China, and found, after text analysis and word frequency analysis, that "Teacher centered" is still the mainstream mode of university teaching at present, and the "student-centered" concept has not been widely recognized by teachers. To reform current teaching methods has become the pressing task for undergraduate education in China. Likewise, translation teaching is confronted with the difficulty of arousing students' learning enthusiasm and promoting their effective learning. Traditional translation teaching of non-English majors usually takes translation as a way to improve students' English skills, rather than treats it as an independent subject. 
Teachers assign translation exercises (usu. sentence translation) to students, and then comment on their translations in class. Such a teaching-centered mode deprives students of their initiative in learning since it neglects learners' learning process. Therefore, it does little good to improving students' translation ability. Since translation can only be learned by practicing it, it is of great significance to introduce "translation workshop" into translation teaching, which can surely improve students' learning effect and critical thinking ability by allowing them to learn translation through discussion and cooperation.

\subsection{Definition of Translation Workshop}

The term "workshop" was first used in the field of educational psychology, and later introduced into urban planning by Lawrence Harpin, an American landscape architect. It means that people holding different positions get together for discussion and exchanging ideas, or that many people engage in a systematic process consisting of activities (such as dialogue, communication, joint discussion, investigation, analysis of problems, planning, etc.) in a relaxed and interesting interactive way ( $\mathrm{Li} \&$ Zhong, 2010). Translation workshop first appeared in the 1920s when North American Translation Workshop was co-organized by the University of Iowa and Princeton University (Yang \& Li, 2015). According to Gentzler (1993) director of the Translation Center at the University of Massachusetts, translation workshop is a forum similar to a translation center, in which two or more translators gather to engage in translation activities, or, "a group of people engaged in translation activities gather together and have a wide and enthusiastic discussion on a specific translation task to produce a version accepted or agreed by all members of the group." (Li \& Zhong, 2010).

\subsection{Instructional Design of Translation Workshop}

3.2.1. Guidelines for the Instructional Design

In adherence to the "student-centered" and "outcome-based" concept, the teaching reform strives to solve the problems of traditional translation teaching, such as being time-consuming and inefficient, neglecting the translation process, and failing to meet social needs. In line with student-centered course design idea, the instructional design starts with setting teaching objectives, and then devises assessment measures to evaluate the attainment of student outcomes. Students' learning methods, the teacher's teaching methods and teaching activities are accordingly designed to help attain teaching objectives. After the lesson, student outcomes are evaluated and evaluation results in decisions and actions regarding continuous improvement. As shown in Figure 1, the whole design idea follows the "student-centered" education concept and focuses on students' learning process and the attainment of student outcomes.

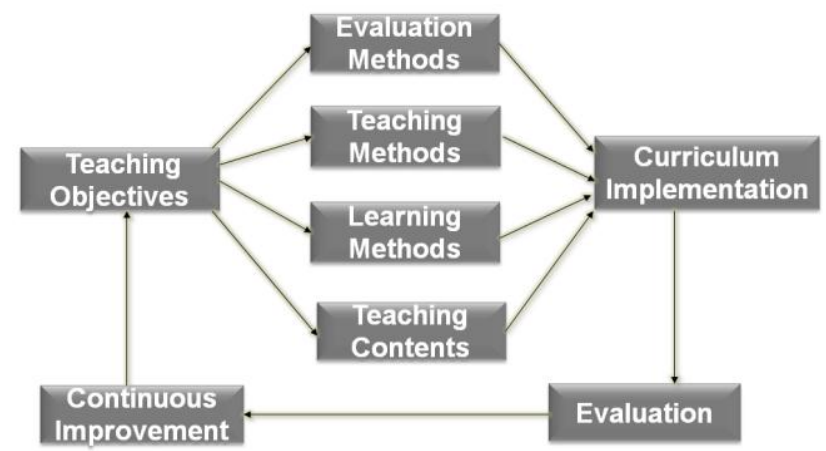

Figure-1. Outcome-based translation workshop instructional design.

3.2.2. Design of Teaching Objectives

3.2.2.1. Analysis of Learner Needs

1) Majors and grades of the enrolled students
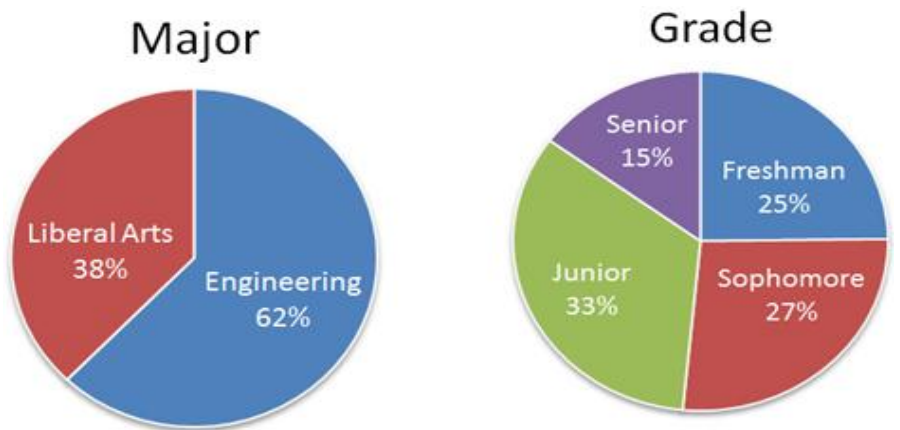

Figure-2. Majors and grades of students enrolling in the course 
Statistics show that in the past five semesters, 262 students selected the course "College English Translation" at the institute where the author teaches, $38 \%$ of whom were liberal arts students and $62 \%$ were engineering students; $60 \%$ of the students were sophomores and juniors, $25 \%$ were freshmen and $15 \%$ were seniors.

2) Motives for enrolling in the course

A survey was conducted to find out why students selected the course and what they knew about translation before taking the course. It was found that of the 129 students surveyed, nearly $82 \%$ took the course for the purpose of passing CET-4 or CET-6, and nearly $41 \%$ selected it in order to prepare themselves for the postgraduate entrance examination. Students with these two motives came from both majors and all grades, which shows that a common purpose for selecting this course is to improve English level. $64.1 \%$ the surveyed students chose "getting the required credit for graduation" as the purpose, but only $7.8 \%$ of them took this as the only purpose, most of whom were senior students. $30.77 \%$ of the surveyed chose to enhance their cross-cultural communication ability, among whom 50\% were liberal arts students and $25 \%$ were engineering students, which proves liberal arts students usually have higher requirements on their English level and thus higher expectations of the course than engineering students.

\section{Motives for Enrollment}

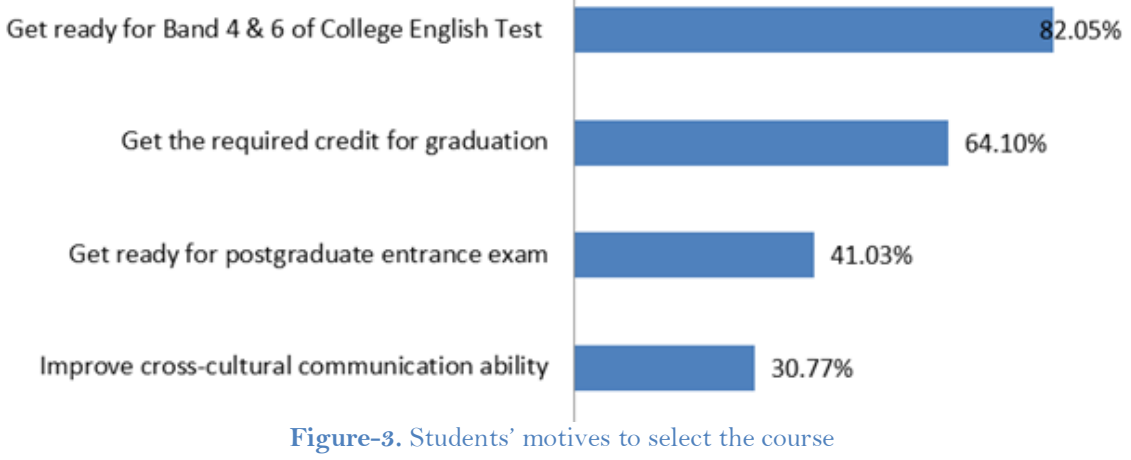

In general, more than $90 \%$ of the surveyed students hope to improve their English level through translation learning. Therefore, the teacher should make students fully aware of the important role of translation in their professional study and future work, and try to mobilize students' motivation for active learning through careful instructional design.

\subsubsection{Teaching Objectives for the Course}

Based on the analysis of learner needs, four teaching objectives are designed following Bloom's Taxonomy and the Guideline on College English Teaching in China, including one lower-order objective and three higher-order objectives.

Learning objective 1: be able to explain basic translation theories, translation terms and translation skills. (memorization and understanding).

Learning objective 2: be able to compare and analyze the cultural and linguistic differences between China and the West, so as to help apply translation knowledge to solve translation problems. (application and analysis).

Learning objective 3: be able to facilitate the smooth implementation of team tasks by assuming the duties of a translator in a translation project and by summarizing translation experience in a timely manner. (evaluation).

Learning objective 4: be able to communicate effectively in a cross-cultural environment by developing an unbiased view towards cultural differences. (humanistic spirit).

\subsubsection{Teaching Procedures of Translation Workshop Mode}

1) Pre-class task

(1) Project assignment

The teacher assigns the translation task and divides the class into groups of 3-4 students, one student being the translation project manager and the others being translators. Team members take turns to be the project manager who is responsible for coordinating, communicating and monitoring the whole translation process. 


\section{(2)Project implementation}

The teacher uploads learning materials and translation tasks on the translation teaching platform, making clear the translation requirements and submission deadlines. Each project team hold a start-up meeting to discuss and decide on the division of work: collecting reference materials, preparing terminology, recording minutes of the meeting, translating, etc. After team members finish their translation work independently, they cross check their translations, discuss translation problems and agree on the final version to be presented in class. The team need to proofread the following aspects before deciding on their final version: whether the translation is complete; whether the content and terminology are accurate; whether the grammar and collocations are correct; whether the format, punctuation and symbols in the translation are properly used.

2) In-class presentation

(1)Different groups present their final versions and raise their translation problems for class discussion.

(2) Students contribute their ideas on how to solve the problems raised by the presentation group and make comments on the presented versions.

(3) The teacher guides students to have in-depth discussion, summarizes the key points and solutions to problems, and helps students connect current knowledge and skills with their prior knowledge and thus facilitates deep and meaningful learning.

3) Post-class summary

Each project team submits their final version after revising it according to the comments of their peers and the teacher and summarizes what they've learned from this translation project. The whole process is shown in Figure 4.

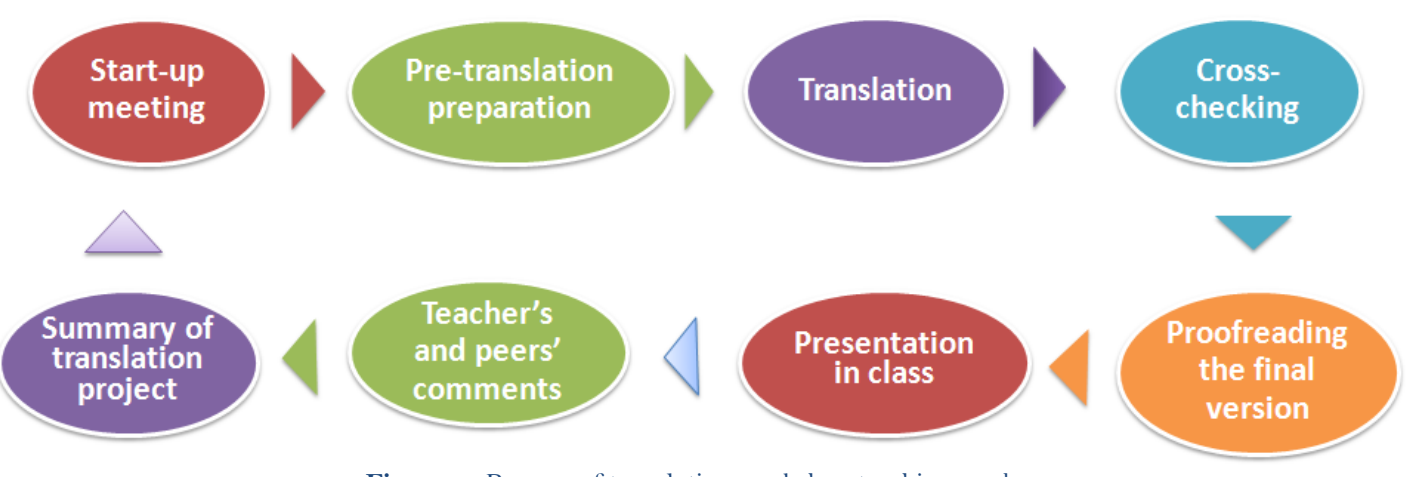

Figure-4. Process of translation workshop teaching mode.

\subsubsection{Design of Assessment Measures}

The teaching mode of "translation workshop" centers on students' learning and attaches great importance to students' learning process. Appropriate quantitative and qualitative assessment measures are devised to determine the extent to which student outcomes are being attained. The final mark consists of $70 \%$ formative evaluation and $30 \%$ summative evaluation (final examination). The formative evaluation measures include online and offline translation work, meeting minutes, cross-checking translation, in-class presentation, discussion \& debate, revised final version, and project report. Table 1 shows the objectives attainment matrix and the evaluation criteria for each measure.

\subsection{Effect of Applying Translation Workshop to Translation Teaching}

After one semester's teaching reform, the result of assessment reveals that the mode of translation workshop works very well with the students, which allows them to freely express themselves and work on their own translation problems before the class. During the class, students can focus on the problems which remain unresolved and try to find the answer through class discussion and teacher's guide, so it enhances classroom teaching efficiency.

After the reform, a questionnaire was given to students to find out how they evaluate their learning. Students' self-evaluation shows that $96.67 \%$ of the 39 surveyed students speak highly of translation workshop teaching mode since it can strengthen their critical thinking ability and teamwork spirit; $95 \%$ think that the mode can effectively improve their cross-cultural communication ability; about $94 \%$ praise the mode for being able to stimulate their learning interest and $90 \%$ hold that this course has improved their translation ability.

Therefore, in view of the above evaluation feedback, the future translation teaching of non-English majors should continue to be guided by the social demand for talents, and focus on cultivating students' cross-cultural communication ability. Since some students complain about the difficulty of the original text, the teacher should reduce the difficulty of future translation assignments to sustain students' interest in learning translation and help them walk out of their comfort zone step by step. At the same time, multi teaching modes 
like "online+offline" mode and flipped classroom teaching can be adopted to expand the time and space of students' autonomous learning and active learning.

Table-1. Objectives attainment matrix and evaluation criteria.

\begin{tabular}{|c|c|c|c|c|}
\hline Total Mark & $\begin{array}{l}\text { Assessment } \\
\text { Measures }\end{array}$ & Points & Evaluation Criteria & $\begin{array}{l}\text { Objectives } \\
\text { Attained }\end{array}$ \\
\hline \multirow{7}{*}{$\begin{array}{l}\text { Formative } \\
\text { Evaluation } \\
(70 \%)\end{array}$} & $\begin{array}{l}\text { Translation } \\
\text { work }\end{array}$ & 15 & $\begin{array}{l}\text { Students independently complete the online } \\
\text { and offline translation exercises. The } \\
\text { assessment points include: being able to } \\
\text { reorganize the original information according } \\
\text { to cultural and linguistic differences; the } \\
\text { translation conveys the original message and } \\
\text { conforms to the writing habits of the target } \\
\text { language ( } 10 \%) \text {; being able to submit } \\
\text { assignments on time to show the ability of } \\
\text { autonomous learning }(5 \%) \text {. }\end{array}$ & $\begin{array}{l}\text { Objective } 1 \text {, } \\
2 \& 4\end{array}$ \\
\hline & $\begin{array}{l}\text { Cross- } \\
\text { checking }\end{array}$ & 10 & $\begin{array}{l}\text { After independently completing the } \\
\text { translation exercises, team members cross } \\
\text { check their translations. Their cross-check } \\
\text { will be assessed from the aspects like whether } \\
\text { the language errors in the translation are } \\
\text { marked and whether the failure to convey the } \\
\text { original meaning is pointed out. }\end{array}$ & $\begin{array}{l}\text { Objective } 1, \\
2 \& 3\end{array}$ \\
\hline & $\begin{array}{l}\text { In-class } \\
\text { presentation }\end{array}$ & 5 & $\begin{array}{l}\text { Each team prepares slides to present their } \\
\text { final version and raise their translation } \\
\text { problems. What they present in class should } \\
\text { show they are well prepared, for example, the } \\
\text { problems raised are challenging or the } \\
\text { solutions proposed reflect the results of joint } \\
\text { discussion. }\end{array}$ & $\begin{array}{l}\text { Objective } 1, \\
2,3 \& 4\end{array}$ \\
\hline & $\begin{array}{l}\text { Discussion\& } \\
\text { debate }\end{array}$ & 15 & $\begin{array}{l}\text { In class, all students should discuss and } \\
\text { answer the questions raised by the teacher } \\
\text { and the presentation group. Every time } \\
\text { students answer a question, express } \\
\text { themselves or question others can earn } \\
\text { themselves half a point. }\end{array}$ & $\begin{array}{l}\text { Objective } 1, \\
2,3 \& 4\end{array}$ \\
\hline & $\begin{array}{l}\text { Revising final } \\
\text { version }\end{array}$ & 10 & $\begin{array}{l}\text { After class, each team should revise their final } \\
\text { version according to the feedback of the } \\
\text { teacher and their peers. The revision should } \\
\text { cover all the mistakes or inappropriateness } \\
\text { pointed out by the teacher in class. }\end{array}$ & $\begin{array}{l}\text { Objective } 1, \\
2 \& 3\end{array}$ \\
\hline & $\begin{array}{l}\text { Meeting } \\
\text { minutes }\end{array}$ & 5 & $\begin{array}{l}\text { The project manager (team leader) should } \\
\text { organize and hold project meetings at } \\
\text { different stages of the project, record what is } \\
\text { discussed, and submit the minutes of each } \\
\text { meeting after the project is completed. }\end{array}$ & $\begin{array}{l}\text { Objective } 2 \\
\& 3\end{array}$ \\
\hline & Project report & 10 & $\begin{array}{l}\text { After each project, every student should write } \\
\text { a report reflecting on what knowledge and } \\
\text { skills are acquired, what ability is developed, } \\
\text { and what lessons can be learned. }\end{array}$ & $\begin{array}{l}\text { Objective } 1, \\
2,3 \& 4\end{array}$ \\
\hline $\begin{array}{l}\text { Summative } \\
\text { Evaluation } \\
(30 \%)\end{array}$ & Final exam & 30 & $\begin{array}{l}\text { The final examination consists of two parts, } \\
\text { E-C and C-E text translation exercises. } \\
\text { Points will be given to faithful conveyance of } \\
\text { the original meaning, correct use of } \\
\text { vocabulary, right syntax, and varied sentence } \\
\text { patterns. }\end{array}$ & $\begin{array}{l}\text { Objective } 1 \\
\& 2\end{array}$ \\
\hline
\end{tabular}




\section{Students' Self-Evaluation after Learning}

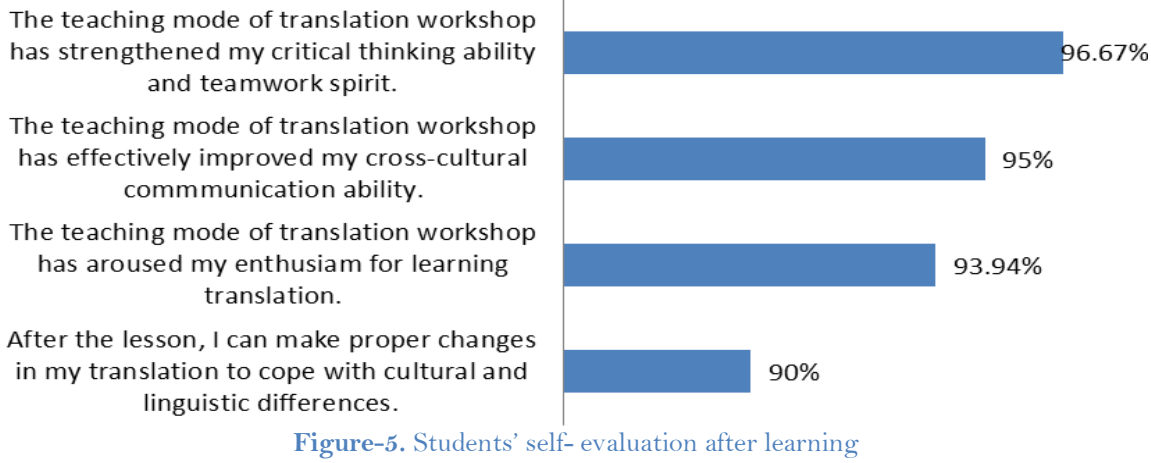

\section{Conclusion}

The experiment proved translation workshop has beneficial effect on improving translation teaching quality. Translation workshop brings hands-on experience into the classroom and attaches importance to the learning process and students' active involvement in learning, so it can effectively motivate students' enthusiasm for learning and improve their learning effect. Throughout the process, the teacher should respect students' subject status and provide them with scaffolding to learn translation, so that students can sharpen their ability to identify, analyze and solve problems, which lays a solid foundation for students' international development.

\section{References}

Chen, X. Z., Li, Z. Y., \& Hu, R. (2012). Practice errors and guiding principles on "student-centered" undergraduate education. China Higher Education Research, 28(11), 57-63.

Chen, F. (2017). How to make student-centered teaching possible-an empirical study on the status quo of undergraduate classroom teaching in 51 universities. Journal of Higher Education, 38(10), 75-82.

Gentzler, E. (1993). Contemporary translation theories. London: Routledge.

Li, M., \& Zhong, W. H. (2010). A guide for conducting translation workshop. Chinese Translators Journal, 31 (4), 91.

Liu, Z., \& Zhao, X. Q. (2018). Practice of "student-centered" undergraduate education reform. China Adult Education, 27(13), 97-99.

Liu, X. J. (2012). On the Student-centered Ideal. Journal of Higher Education, 33(8), 1-6.

Yang, Y. J., \& Li, A. (2015). Experimental study of workshop mode embedded in English translation teaching. Education Research Monthly, 32(12), 97-103. 